\title{
CFD-SIMULATION OF THE PYROLYSIS PROCESS OF HIGH-TEMPERATURE DECOMPOSITION OF RAW MATERIALS OF PLANT ORIGIN IN HOUSEHOLD SOLID- FUEL BOILERS
}

\author{
M. Haldinov, V. Peshko, D. Rindyuk, O. Chernousenko \\ National Technical University of Ukraine "Igor Sikorsky Kyiv Polytechnic Institute" \\ S. Lementar \\ National University of Food Technologies
}

\begin{tabular}{l}
\multicolumn{1}{c}{ Key words: } \\
Pyrolysis \\
Combustion \\
Synthesis gas \\
Household solid-fuel \\
boilers \\
CFD-simulation \\
Coefficient of oxygen \\
excess \\
\hline \multicolumn{1}{c}{ Article history: } \\
Received 02.03.2018 \\
Received in revised form \\
21.03.2018 \\
Accepted 09.04.2018 \\
\hline
\end{tabular}

Corresponding author:

S. Lementar

E-mail:

npnuht@ukr.net

\begin{abstract}
The usage of alternative and renewable energy sources is appropriate for energy sector of Ukraine. The paper is devoted to modeling the decomposition and combustion of plant raw materials processes in household solid-fuel boilers (HSFB). It is shown, that the efficiency of HSFB depends on a large extent of its operational and constructive parameters. The advantages and expediency of the use of information technologies for the analysis of the mutual influence of the majority of structural and technological parameters of processes which are taking place in household solid-fuel boilers are noted. An informational technology of research of processes occurring in HSFB is offered. A general case of the pyrolysis high-temperature decomposition of raw materials, construction and the principle of work of household solid-fuel boilers are considered. A complex model of simulation of high-temperature pyrolysis decomposition of plant fuels is proposed.

Since pyrolytic high-temperature decomposition of wood, taking into account the heat exchange between combustion fluxes and coolant is a rather complicated process, the modular modeling method is used. The first stage is twophase combustion with a lack of oxygen in the gas-generating chamber. The model describes the processes of combustion of liquid and solid fuel at subsonic gas flow rates. The second stage is the single-phase burning of volatiles in the combustion chamber. Volatile combustion models are chosen depending on the speed of the gross reaction. The third stage is the simulation of the heat exchange process between the combustion products and the coolant in a fire-cell element.

The result of the simulation is the diagram of the distribution of the coefficient of oxygen excess, temperature and velocity at all stages of the simulation. The developed model and the data obtained in the simulation allow to establish the relationship between the technological and constructive parameters of the HSFB. It is also possible to provide recommendations on the rationalization of construction for existing household boilers and to propose new constructive solutions.
\end{abstract}

DOI: $10.24263 / 2225-2924-2018-24-2-20$ 


\section{CFD-МОДЕЛЮВАННЯ ПРОЦЕСУ ПІРОЛІЗНОГО ВИСОКОТЕМПЕРАТУРНОГО РОЗКЛАДАННЯ СИРОВИНИ РОСЛИННОГО ПОХОДЖЕННЯ У ПОБУТОВИХ ТВЕРДОПАЛИВНИХ КОТЛАХ}

\section{М.В. Галдінов, В.А. Пешко, Д.В. Риндюк, О.Ю. Черноусенко}

Національний технічний університет Украйни «Київський політехнічний інститут ім. I. Сікорського»

\section{С.Ю. Лементар}

Національний університет харчових технологій

У статті проведено моделювання процесу розкладання та горіння рослинної сировини у твердопаливному піролізному побутовому котлі (ТППК), оскільки використання нетрадиційних $i$ відновлюваних джерел енергї̈ $\epsilon$ доиільним для енергетики України. Показано, щзо ефективність ТППК значною мірою залеэсить від його режимних $і$ конструкиійних параметрів. Відмічені переваги та доиільність використання інформаційних технологій для аналізу взаємовпливу більшості конструктивно-технологічних параметрів прочесів, що проходять у побутових твердопаливних котлах. Запропоновано інформачійну технологію дослідження процесів, що відбуваються у ТППК. Розглянуто загальний випадок процесу піролізного високотемпературного розкладання сировини рослинного походження, конструкиію та принцип роботи твердопаливного піролізного побутового котла. Запропоновано комплексну модель симуляиії процесів високотемпературного піролізного розкладання палива рослинного походження.

Оскільки піролізне високотемпературне розкладання деревини з урахуванням теплообміну між потоками продуктів згоряння й теплоносієм є досить складним прочесом, використано метод модульного моделювання. Першим етапом є двофазне горіння при нестачі кисню в камері газогенерачії. Модель описує процеси горіння рідкого і твердого палива при дозвукових швидкостях течії газу. Другим етапом є однофазне горіння летких у камері згоряння. Моделі горіння летких обираються залежно від швидкості перебігу бруттореакиії. Третім етапом є моделювання процесу теплообміну між продуктами згоряння та теплоносієм у жаротрубному елементі, щзо базується на розв'язку рівняння енергї з урахуванням радіащійної складової теплового потоку, Нав'єСтокса і рівняння для турбулентних функиій переносу.

Результатом моделювання $\epsilon$ епюри розподілу коефічієнта надлишку повітря, температури та швидкостей на всіх етапах моделювання. Створена модель й отримані в результаті моделювання дані дають змогу встановити зв'язок між конструктивно-технологічними параметрами ТППК та надати рекомендації щодо раціоналізації конструкиї як існуючих побутових котлів, так і запропонувати нові конструктивні рімення.

Ключові слова: піроліз, горіння, синтез-газ, твердопаливні побутові котли, CFD-моделювання, коефіцієнт надлишку повітря. 
Постановка проблеми. Енергетична криза та різке підвищення цін на енергоносії вимагають звернути докладну увагу на модернізацію існуючих i використання нових технологій отримання теплової й електричної енергії.

Актуальність дослідження обумовлена стрімким розвитком альтернативної енергетики та енергоощадних технологій в усьому світі.

Зважаючи на вищевказане, виникає необхідність у збільшенні використання альтернативних джерел енергії та підвищенні технічного рівня відповідного обладнання. Поступове вичерпання традиційних енергоносіїв і висока вартість енергоресурсів примушують докладно розглянути, у тому числі, i проблему опалення приватних будинків. Розглянувши існуючі технології, відмітимо, що для території України економічно доцільним для опалення приватних будинків $\epsilon$ використання піролізних побутових котлів.

Ринок України в достатній мірі забезпечено великою кількістю типів побутових піролізних котлів як вітчизняного, так і закордонного виробництва. Також безпосередньо сам процес піролізного високотемпературного розкладання сировини рослинного походження достатньо докладно описано у відповідній науковій літературі. Проте аналіз літературних джерел показав, що зв'язок між конструктивними параметрами існуючих типів піролізних побутових котлів і процесом піролізного високотемпературного розкладання сировини з урахуванням технологічних параметрів, висвітлено недостатньо.

Отже, виникає необхідність у створенні методики дослідження впливу конструктивно-технологічних параметрів відповідного обладнання на перебіг процесу.

Аналіз останніх досліджень і публікацій. Відмітимо, що використання у проектувальній практиці експериментальних фізичних моделей $є$ економічно невигідним, а класичні емпіричні залежності та експериментальний досвід, що традиційно застосовуються для проектних розрахунків, не дають змоги врахувати всі технологічні особливості (нагрівання та формозмінення деталей конструкції, поведінку потоків газів та ін.) та дати кількісну оцінку взаємовпливу конструктивно-технологічних параметрів і поведінки потоків газів у процесі піролізного високотемпературного розкладання сировини рослинного походження [1].

Тому для аналізу взаємовпливу більшості конструктивно-технологічних параметрів процесів, що проходять у побутових твердопаливних котлах, доцільно використовувати інформаційні технології проектування [2].

Ефективна реалізація технологій спалювання сировини за допомогою твердопаливних піролізних побутових котлів (ТППК) значною мірою залежить від конструктивних особливостей відповідного обладнання, що забезпечує необхідні експлуатаційні показники.

Враховуючи широку номенклатуру типів ТППК та палива, при проектуванні відповідного обладнання виникає проблема визначення взаємозв'язку між конструктивно-технологічними параметрами основних вузлів ТППК.

Оскільки таких параметрів існує достатньо значна кількість, то необхідно визначити раціональний розподіл відповідних конструктивно-технологічних параметрів. 
Аналіз останніх досліджень показав, що сучасні інформаційні технології проектування [3] дають можливість визначити кількісні та якісні закономірності процесів взаємодії різних типів палива із елементами технологічного обладнання для заданих схем роботи ТППК. Використання таких методів дає змогу отримати залежності між параметрами для подальшої побудови математичної моделі.

Математичне моделювання процесів горіння й теплообміну з урахуванням конструктивно-технологічних особливостей ТППК $є$ достатньо ефективним методом дослідження, основною метою якого є удосконалення конструкції відповідного обладнання.

Розглянемо загальний випадок процесу піролізного високотемпературного розкладання сировини рослинного походження.

Піроліз деревини (суха перегонка деревини) - розкладання деревини при нагріванні до $450{ }^{\circ} \mathrm{C}$ без доступу повітря з утворенням газоподібних і рідких (в т. ч. деревної смоли) продуктів, а також твердого залишку - деревного вугілля.

В основі піролізу деревини лежать вільнорадикальні реакції термодеструкції гемицелюлоз, целюлози та лігніну, що відбуваються, відповідно, при $200-260^{\circ} \mathrm{C}, 240-350^{\circ} \mathrm{C}$ і $250-400^{\circ} \mathrm{C}$; співвідношення констант швидкостей при $320^{\circ} \mathrm{C}$ становить $10: 1: 0,25$. Кінетичні характеристики піролізу деревини та іiі компонентів, знайдені різними авторами, помітно різняться. Реакції розпаду деревини, геміцелюлози, целюлози та лігніну мають перший порядок, а енергії активації цих реакцій змінюються в значних межах; для згаданих компонентів деревини, відповідно, 70-80, 135-210 і 55-110 кДж/моль [4]. Константа швидкості піролізу деревини вища, ніж у целюлози, i, наприклад, при $350^{\circ} \mathrm{C}$ для різних порід знаходиться в діапазоні $(2,8-8,3) 10^{-3} \mathrm{c}^{-1}$. Піроліз деревини - екзотермічний процес, при якому виділяється велика кількість теплоти (1150 кДж/кг).

На підставі лабораторних дослідів можна зробити висновок, що швидкість процесу справляє помітний вплив в основному на стадію розпаду, що проходить в інтервалі температур $260-290^{\circ} \mathrm{C}$. Інтенсивна подача тепла в цей час для подрібненої деревини веде до підвищення виходу смоли і зниження виходу вугілля при практично не змінних виходах низькомолекулярних продуктів: кислоти, метанолу, альдегідів. Можна припустити, що при повільному нагріванні частина смоли коксується на поверхні вугілля, збільшуючи його вихід i, одночасно, кисень, що знаходиться в деревині, асимілюється 3 воднем, даючи воду, і з вуглецем - $\mathrm{CO}_{2}[5]$.

Продукти, що виділяються при піролізі деревини, утворюються в широкому діапазоні температур. Кожен з продуктів має певну температуру початку утворення, свій максимум і кінець утворення. Максимуми переважного числа продуктів термічного розпаду деревини відносяться до температурного інтервалу, відповідної екзотермічної реакції (виділення надлишкового тепла).

Розглянемо загальну конструкцію та принцип роботи твердопаливного піролізного побутового котла. 
Конструкція ТППК передбачає наявність таких складових: сталевий корпус, зварений з листів товщиною 5-7 мм, камера згоряння і кілька керамічних блоків. У задній частині цього обладнання $є$ колектор продуктів спалювання, оснащений витяжним вентилятором. У передній частині - завантажувальні (верхня і нижня) дверцята. Подача головного повітря гарантується завдяки регулювальним сегментам, розташованим у бічних панелях. Що стосується вторинного повітря, то воно нагрівається в задній частині і по трубах відправляється в форсунку. Сформований піролізний газ у топці за допомогою витяжного вентилятора направляється в камеру згоряння, де відбувається його змішування з вторинним повітрям.

До переваг даного типу котлів відносять: високу ефективність (85-92\%), менші затрати вторинного повітря, і, відповідно, більшу температуру й ефективність, процедурою спалювання піролізного газу простіше управляти, таким чином, процес функціонування піролізного (газогенераторного) котла легко автоматизувати [6; 7]. Численні дослідження показали, що двоокис вуглецю буде викидатися в навколишнє середовище до трьох разів менше, ніж від звичайного дров'яного і, тим більше, вугільного котла [8].

Мета дослідження: розробка методів дослідження впливу конструктивнотехнологічних параметрів на основні процеси, що відбуваються в ТПК для подальшого удосконалення конструкції.

Матеріали і методи дослідження. Проведений аналіз процесу високотемпературного розкладання палива органічного походження та існуючих конструкцій твердопаливних піролізних побутових котлів дає змогу отримати необхідні дані для створення математичної моделі.

Піролізне високотемпературне розкладання деревини з урахуванням теплообміну між потоками продуктів згоряння й теплоносієм $є$ досить складним процесом. У таких випадках доцільно використовувати модульне моделювання. Суть цього медоту полягає в розбитті складної задачі на декілька більш простих. Вхідними параметрами для кожного наступного етапу є вихідні параметри попереднього. В математичній моделі використано ряд спрощень. Процес горіння в ТППК був розподілений на три основні етапи (рис. 1).

Перший етап - двофазне горіння при недостачі кисню в камері газогенерації. На цьому етапі відбувається виліт летких і горіння твердого залишку.

Модель течії з двофазним горінням описує процеси горіння рідкого і твердого палива при дозвукових швидкостях течії газу. В основі моделі лежать такі припущення [9]: краплі рідкого палива випаровуються в розрахунковому об'ємі, горіння парів палива відбувається в газовій фазі; частинки твердого палива спочатку випускають леткі, а потім горить коксовий залишок. Горіння летких відбувається в газовій фазі, горіння коксу - на поверхні частинки. У процесі піролізу (виходу летких) розмір частки залишається незмінним (змінюється ії щільність). У процесі горіння коксового залишку щільність частки залишається незмінною (змінюється ії діаметр). Масова частка золи в коксовому залишку залишається незмінною; газова фаза представлена такими компонентами: леткі, $\mathrm{O}_{2}, \mathrm{~N}_{2}, \mathrm{CO}_{2}, \mathrm{H}_{2} \mathrm{O}$; частинка - це капсула, що містить обумовлені масові частки летких, коксу, золи і вологи. 


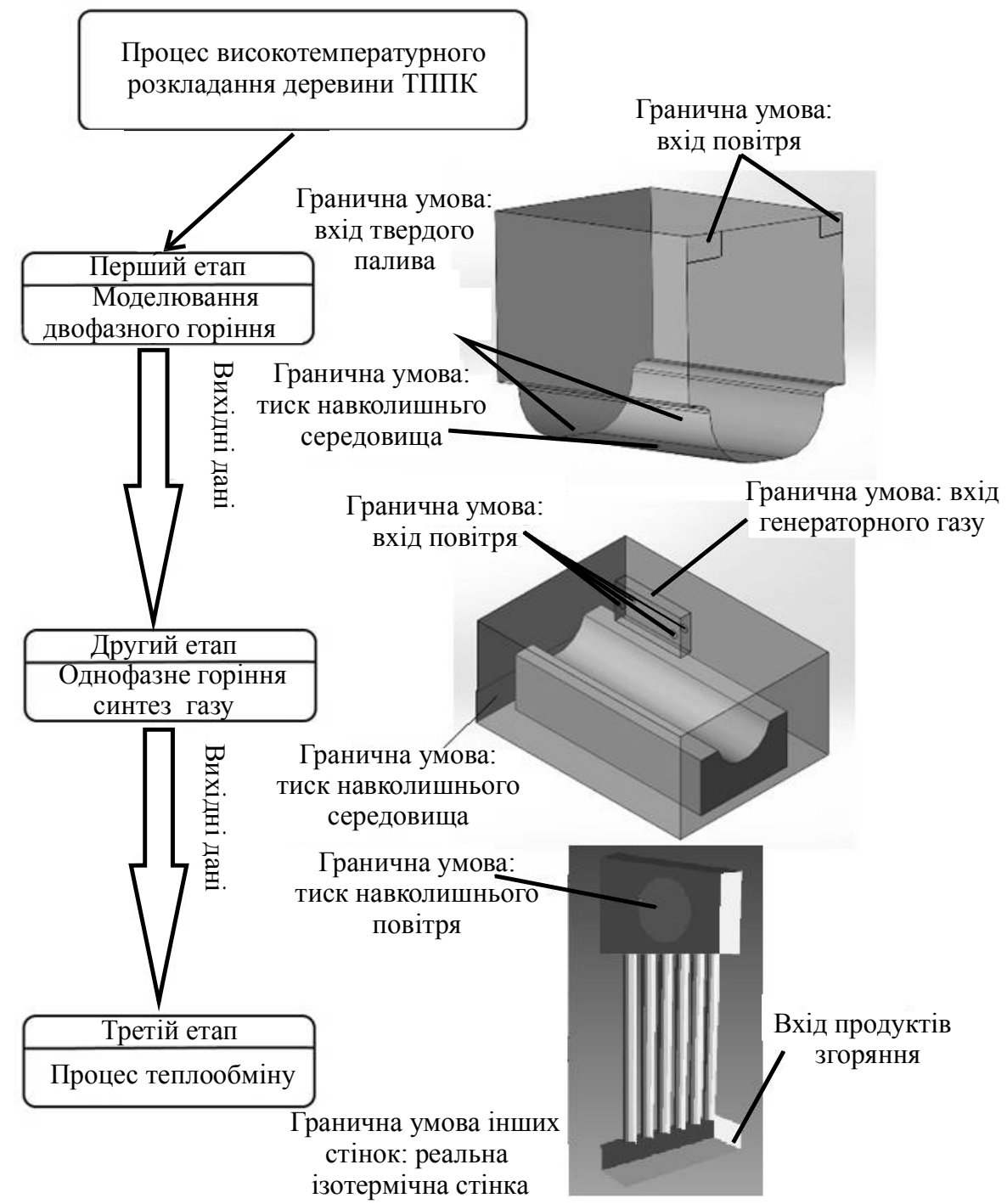

Рис. 1. Схема інформаційної технології дослідження

Якщо частинка рідка, то масові частки коксу, золи і вологи задаються рівними нулю; узагальнена формула рідкого палива і летких: $\mathrm{C}_{x} \mathrm{H}_{y} \mathrm{O}_{z}$; леткі вважаються складеними із шести компонентів: $\mathrm{CH}_{4}, \mathrm{H}_{2}, \mathrm{CO}, \mathrm{CO}_{2}, \mathrm{H}_{2} \mathrm{O}$, пари смоли; окислювач: $\mathrm{O}_{2}$; відпрацьовані гази: $\mathrm{CO}_{2}$ i $\mathrm{H}_{2} \mathrm{O}$; процеси, що відбуваються за участю азоту і сірки не моделюються. Однак інтегральний тепловий ефект цих процесів враховується [9]. Використану модель процесу піролізу докладно описано в [10].

Другим етапом $є$ однофазне горіння летких у камері згоряння. Вхідні дані (кількісні та якісні параметри продуктів згоряння) для цього етапу були отримані з попереднього етапу. 
Модель горіння базується на таких рівняннях:

Рівняння Нав'є-Стокса:

$$
\begin{aligned}
\frac{\partial \rho V}{\partial t}+\nabla(\rho V \otimes V)= & -\nabla P+\nabla\left(\left(\mu+\mu_{t}\right)\left(\nabla V+(\nabla V)^{T}\right)\right)+S, \\
& \frac{\partial \rho}{\partial t}+\nabla(\rho V)=0,
\end{aligned}
$$

де $S=\left(\rho-\rho_{\text {hyd }}\right) g+\rho B+R ; \rho-$ густина рідини, кг $/ \mathrm{M}^{3} ; V$ - вектор відносної швидкості, м/с; $t$ - час, с; $P-$ відносний тиск, Па; $\mu-$ динамічна в'язкість, кг/м'c; $\mu_{\mathrm{t}}-$ турбулентна динамічна в'язкість, кг/м'с; $T-$ відносна температура, $K ; \rho_{\text {hyd }}$ - гідравлічна густина, кг $/ \mathrm{M}^{3} ; g$ - вектор сили тяжіння, м/ $\mathrm{c}^{2} ; B-$ сили обертання (відцентрова і Коріоліса), м/ $\mathrm{c}^{2} ; R-$ сили ізотропного і (або) анізотропного фільтра опору, кг/ $\mathrm{m}^{2} \mathrm{c}^{2}$.

Рівнянні енергій:

$$
\frac{\partial(\rho h)}{\partial t}+\nabla(\rho V h)=\nabla\left(\left(\frac{\lambda}{C_{p}}+\frac{\mu_{t}}{\operatorname{Pr}_{t}}\right) \nabla h\right)+Q,
$$

де $h-$ ентальпія, $\mathrm{m}^{2} / \mathrm{c}^{2} ; \lambda$ - коефіцієнт теплопровідності, Вт/м $\cdot \mathrm{K} ; C_{p}$ питома теплоємність, Дж/кг $К$; $\operatorname{Pr}_{t}$ - турбулентне число Прантля; $Q-$ об’ємна густина теплового потоку, Вт/м³ .

Рівняння для скалярних величин $\xi$, що описують концентрацію палива, окислювача, продуктів згоряння, нейтрального газу, оксидів азоту і маркера:

$$
\frac{\partial(\rho \xi)}{\partial t}+\nabla(\rho V \xi)=\nabla\left(\left(\frac{\mu}{\mathrm{Sc}}+\frac{\mu_{t}}{\mathrm{Sc}_{t}}\right) \nabla \xi\right)+Q,
$$

де $\mathrm{Sc}$ - число Шмідта, $\mathrm{Sc}_{t}$ - турбулентне число Шмідта.

Процес горіння представленно в вигляді брутто-реакції:

$$
1 \kappa_{\text {Палива }}+i \kappa_{\text {Окисника }} \stackrel{W}{\longrightarrow}(1+i) \kappa_{\text {Продуктівзгоряння }},
$$

де $i$ - масовий стехіометричний коефіцієнт; $w$ - осереднена швидкість реакції, кг/ $\mathrm{M}^{3} \cdot \mathrm{c}$.

Моделі горіння летких обираються залежно від швидкості перебігу брутто-реакції: модель Зельдовича, якщо швидкість брутто-реакції $W$ передбачається нескінченно великою; кінетична модель горіння, коли швидкість брутто-реакції $W$ визначається кінетикою процесу, що справедливо при ламінарній течії газової суміші або горінні попередньо перемішаної суміші; модель Магнуссена, якщо швидкість брутто-реакції $W$ визначається швидкістю турбулентного змішування летких і окислювача; пульсаційна модель у випадку, коли швидкість брутто-реакції $W$ визначається відносною дисперсією $\gamma$ концентрації відновлених летких [9].

Третім етапом $є$ моделювання процесу теплообміну, що базується на розв'язку рівняння енергії з урахуванням радіаційної складової теплового потоку, Нав'є-Стокса і рівняння для турбулентних функцій переносу [11; 12]. 
Рівняння енергії з урахуванням випромінення виглядає так :

$$
\frac{\partial\left(h\left(T_{m}\right)\right)}{\partial t}+\vec{\nabla}\left(\rho V h\left(T_{m}\right)\right)=\vec{\nabla} \cdot\left\{-\left(-\left(\frac{\lambda}{C_{p}}+\frac{\mu_{t}}{\operatorname{Pr}_{t}}\right) \vec{\nabla} h\left(T_{m}\right)\right)\right\}+Q_{\text {enth }}^{p}+Q_{\text {rad }},
$$

де $Q_{\text {enth }}^{p}$ - об'ємна густина теплового потоку за рахунок часток, Вт/м ${ }^{3} ; Q_{r a d}-$ об'ємна густина теплового потоку за рахунок випромінення, Вт/м³.

Дифузійна модель випромінення в об’ємі:

$$
\nabla\left(\frac{1}{\alpha+\beta} \nabla E_{r}\right)+3\left(\alpha E_{b}-\alpha E_{r}\right)=0,
$$

де $\alpha-$ інтегральний коефіцієнт поглинання, $1 / \mathrm{m} ; \beta-$ інтегральний коефіцієнт розсіювання, $1 / \mathrm{m} ; E_{r}$ - щільність енергії випромінення, $\mathrm{BT} / \mathrm{m}^{2} ; E_{b}$ рівноважна щільність енергії випромінення, Вт/м².

$$
\begin{gathered}
\alpha=\alpha_{m} E_{b, m}+\alpha_{p} E_{b, p} ; \\
\alpha=\alpha_{m}+\alpha_{p} ; \\
\beta=\beta_{m}+\beta_{p} ; \\
E_{b, m}=\sigma_{r a d} T_{m}^{4} ; \\
\alpha_{p} E_{b, p}=\frac{1}{\Omega} \sigma_{r a d} \varepsilon_{p} \sum_{i=\text { trajectories }} \pi r_{i}^{2} N_{i} T_{p, i}^{4} ; \\
\alpha_{p}=\frac{1}{\Omega} \varepsilon_{p} \sum_{i=\text { trajectories }} \pi r_{i}^{2} N_{i} ; \\
\beta_{p}=\frac{1}{\Omega}\left(2-\varepsilon_{p}\right) \sum_{i=t r a j e c t o r i e s} \pi r_{i}^{2} N_{i} ; \\
Q_{r a d}=-4 \alpha n^{2}\left(E_{b}-E_{r}\right) ;
\end{gathered}
$$

де $\sigma_{\text {rad }}-$ постійна Стефана-Больцмана; $\Omega-$ об'єм комірки; $\varepsilon-$ ступінь чорноти поверхні; $r_{i}$ - радіус частин $3 i$-ю траєкторією; $N_{i}$ - кількість частинок у цій комірці, $\varepsilon_{p}$ - ступінь чорноти частинки; $n-$ коефіцієнт заломлення, індекс «m» позначає поглинаюче і випромінююче середовище, індекс «р» позначає частинки.

Модель турбулентності побудована на базі $k-\varepsilon$ моделі турбулентності. В цій моделі турбулентна в'язкість $\mu_{t}$ виражається через величини $k$ i $\varepsilon$ таким чином:

$$
\mu_{t}=C_{\mu} \rho \frac{k^{2}}{\varepsilon},
$$

де $k$ - турбулентна енергія, $\mathrm{m}^{2} / \mathrm{c}^{2} ; \varepsilon-$ швидкість дисипації енергії, $\mathrm{m}^{2} / \mathrm{c}^{3}$.

Рівняння для $k$ і $\varepsilon$ : 


$$
\begin{gathered}
\frac{\partial(\rho k)}{\partial t}+\nabla(\rho V k)=\nabla\left(\left(\mu+\frac{\mu_{t}}{\sigma_{k}}\right) \nabla k\right)+\mu_{t} G-\rho \varepsilon, \\
\frac{\partial(\rho \varepsilon)}{\partial t}+\nabla(\rho V \varepsilon)=\nabla\left(\left(\mu+\frac{\mu_{t}}{\sigma_{\varepsilon}}\right) \nabla \varepsilon\right)+C_{1} \frac{\varepsilon}{k} \mu_{t} G-C_{2} \rho \frac{\varepsilon^{2}}{k}, \\
G=C_{\mu} \rho \frac{k^{2}}{\varepsilon}, \\
\operatorname{Re}_{t}=\frac{\rho k^{2}}{\mu \varepsilon},
\end{gathered}
$$

де $\mathrm{Re}_{t}$ турбулентне число Рейнольдса. Значення параметрів $k-\varepsilon$ моделі: $\sigma_{k}=1 ; \sigma_{k}=1,3 ; C_{u}=0,09 ; C_{1}=1,44 ; C_{2}=1,92$.

Викладення основних результатів дослідження. Для розрахунку кожного етапу було створено спрощену просторову 3D модель 3 урахуванням особливостей процесів, які відбуваються на кожному з етапів. На першому етапі розглядається процес піролізу деревини в камері газогенерації. На другому — горіння генераторного газу (кількісні та якісні параметри якого були отримані на першому етапі) в камері згоряння. Як було визначено в [12-14], основна частина теплопередачі відбувається в жаротрубному теплообміннику. Для спрощення моделі на третьому етапі розглядаємо теплообмін тільки в жаротрубному теплообміннику.

Результати проведених обчислювальних експериментів наведено нижче. Розподіл поля температур, швидкості та коефіцієнта надлишку повітря в камері газогенерації зображено на рис. 2, 3. 3 рисунків видно, що коефіцієнт надлишку повітря менше одиниці, що є необхідною умовою для піролізного високотемпературного розкладання палива. Первинне повітря подається в лівій верхній частині камери, відбивається від стінки й спускається до форсунки. Це підтверджує поле швидкості та розподілу температур. Застійна гаряча зона, з низькими швидкостями, знаходиться під місцем подачі повітря. I навпаки, в місці збільшення швидкості температура менша.
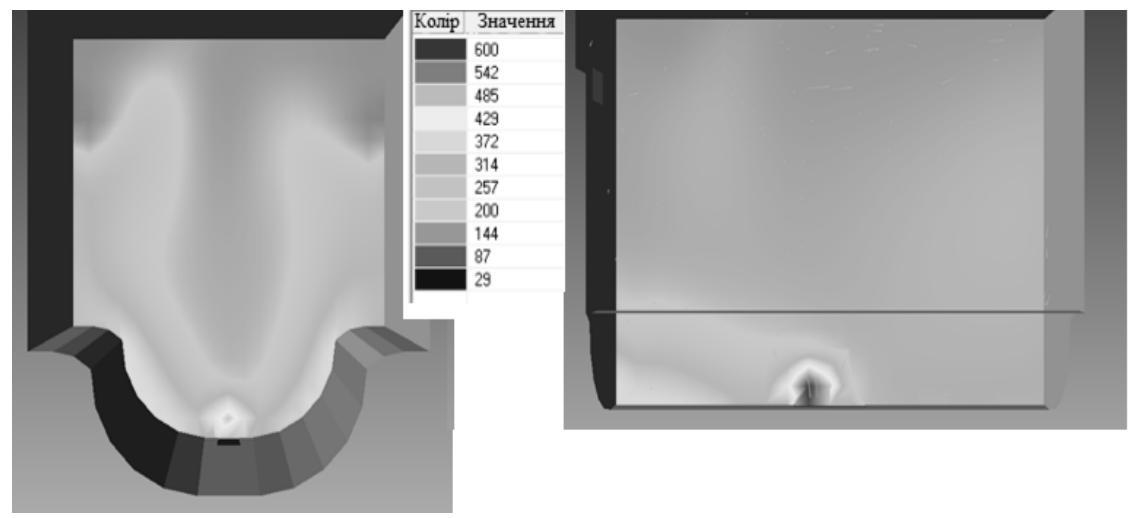

Рис. 2. Розподіл температурного поля, ${ }^{\circ} \mathrm{C}$ 


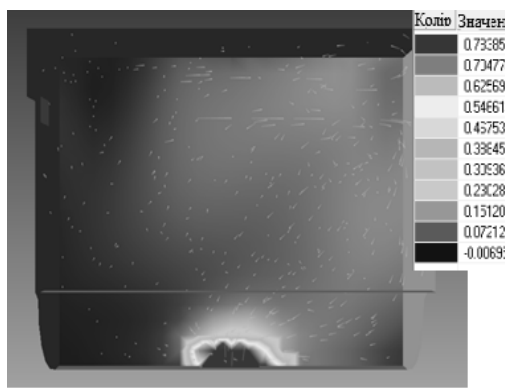

a

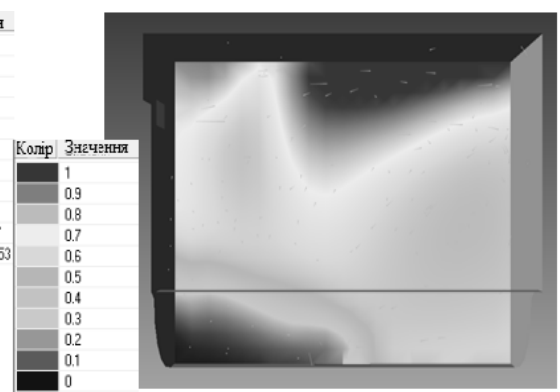

6

Рис. 3. Поле розподілу а) швидкості, м/с та б) коефіцієнта надлишку повітря

Розподіл коефіцієнта надлишку повітря, поля температур і швидкостей у камері згоряння зображено на рис. 4, 5. Продукти згоряння рухаються в бік виходу 3 камери згоряння, це підтверджується полем температур (висока температура біля виходу). 3 форсунки подається повітря 3 температурою $60^{\circ} \mathrm{C}$. Після змішування з генераторним газом відбувається займання та повне згоряння газу. Температура з протилежного від виходу боку нижча.

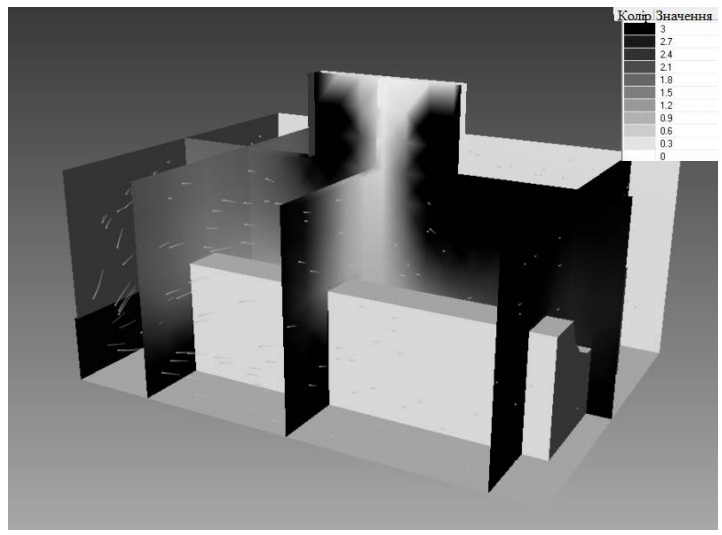

Рис. 4. Розподіл коефіцієнта надлишку повітря



Рис. 5. Розподіл поля швидкостей, м/с 
На третьому етапі створено модель теплопередачі в жаротрубних елементах ТППК. Розподіл температур у жаротрубному елементі зображено на рис. 6. Отримані результати показують, що гарячі димові гази, проходячи через жаротрубний елемент, швидко охолоджуються і температура на виході не перевищує $180^{\circ} \mathrm{C}$, що відповідає реальним ТППК.

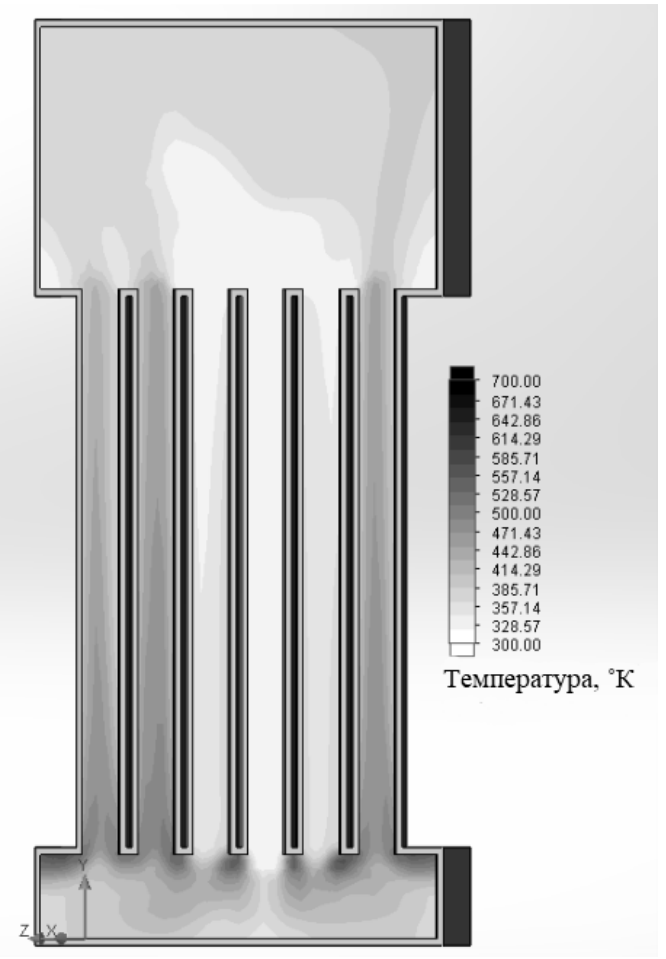

Рис. 6. Розподіл температури в жаротрубному елементі

Отримані картини розподілу коефіцієнта надлишку повітря, температури та швидкості є необхідними для розуміння впливу конструктивно-технологічних параметрів досліджуваного обладнання на перебіг процесів, що проходять в ТППК. Так, наприклад, аналіз розподілу коефіцієнта надлишку повітря дає змогу побачити зони, де відбувається тління $(\alpha<1)$ i, навпаки, зони 3 коефіцієнтом $\alpha>1,05-1,1$ (залежності від виду палива), що свідчать про зменшення температури горіння та, у свою чергу, має значний вплив на екологічність (кількість $\mathrm{NO}_{x}$ ) процесу. Розподіл поля швидкості дає змогу виявити застійні зони. Після аналізу отриманих результатів маємо можливість надати рекомендації для подальшої раціоналізації конструкції ТППК.

\section{Висновки}

Побудована модель та отримані в результаті моделювання дані є одним 3 етапів роботи, що дасть змогу в подальшому створити докладну математичну модель процесу та встановити зв'язок між конструктивними параметрами існуючих типів піролізних побутових котлів і процесом піролізного високо- 
температурного розкладання сировини з урахуванням технологічних параметрів.

Наведене вище показує як необхідність, так і можливість створення сучасної методики проектування твердопаливних піролізних побутових котлів, як одних 3 найбільш перспективних у цій галузі. Описана математична модель дає змогу без зайвих затрат на побудову фізичної моделі експериментувати 3 геометричними розмірами та режимами роботи ТППК. У результаті детального вивчення процесів, які відбуваються в розглянутих котлах, можна надати рекомендації щодо підвищення ефективності роботи та раціоналізації конструкції існуючих та на етапі проектування нових моделей обладнання.

\section{Література}

1. Енергія навколо нас / А.С. Конеченков, М.М. Федосенко, Г.А. Шиловіч та ін. Київ, 1999. - 192 с.

2. Штефан E.B. Информационная технология проектирования технологического оборудования для механической обработки дисперсных материалов / Е.В. Штефан // Межд. период. сб. науч. тр. «Обработка дисперсных материалов и сред. Теория, исследования, технологии, оборудование». Выпуск № 12. — Одесса : НПО «ВОТУМ», 2002. - С. 72-78.

3. Энергетические установки и окружающая среда / под ред. Маляренко В.А. — Харків : ХГАГХ, 2002. - $398 \mathrm{c}$.

4. Bridgewater A. Towards the «biorefi nery» - Fast Pyrolisis of Biomass / A. Bridgewater // Renewable Energy World. V. 4. 2001, № 1 (Jan. — Feb.), P. 66-83.

5. Чирков В.Г. Учет теплофизических свойств при оценке производительности процесса пиролиза растительной биомассы / В.Г. Чирков, Э.Ф. Вайнштейн // Труды 4-й Международной научно-технической конференции (12-13 мая 2004 г., Москва, ГНУ ВИЭСХ) ч. 4. Москва : ГНУ ВИЭСХ, 2004. - С. 245-251.

6. Братута Э.Г. Перспективы использования топочных агрегатов пиролизного типа / Э.Г. Братута, А.Р. Семеней // Энергосбережение, енергетика, энергоаудит. — 2010. № 4/74. - C. 8 - 12 .

7. Семеней А.P. Методика оценки эффективности теплогенератора пиролизного типа в нестационарном режиме эксплуатации / А.Р. Семеней, Э.Г. Братута // Інтегровані технології та ресурсозбереження. — 2010. — № 4. — С. 19-22.

8. Братута Э.Г. Оценка эффективности использования пиролизного теплогенератора в системах тепло- и электроснабжения / Э.Г. Братута, А.Р. Семеней // Энергосбережение, энергетика, энергоаудит. - 2011. - № 5. - С. $23-28$.

9. Сухоикий А.Б. Система моделирования движения жидкости и газа FlowVision версия 2.5.4. Руководство пользователя / А.Б. Сухоцкий. - Москва : ООО «ТЕСИС», 2008. - С. 279.

10. Бабий В.И. Горение угольной пыли и расчёт пылеугольного факела / В.И. Бабий, Ю.Ф. Кував. - Москва : Энергоатомиздат, 1986. — 208 с.

11. Aksenov A. Fluid Structure Interaction analysis using Abaqus and FlowVision / A. Aksenov, A. Dyadkin, T.Lunewski, V.Pokhilko // Proc. 2004 Abaqus user conference. Boston, 2004.

12. Степанов Д.В. Математичне моделювання теплообмінних процесів у жаротрубному елементі водогрійного котла малої потужності / Д.В. Степанов, С.Й. Ткаченко, Л.А. Боднар // Вісник Вінницького політехнічного інституту — 2007. — № 2. - С. 66-69.

13. Степанов Д. В. Тенденції розвитку теплогенерувального обладнання на твердому паливі / Д.В. Степанов, С.Й. Ткаченко, Л.А. Боднар // Вісник Вінницького політехнічного інституту. - 2008. - № 3. - С. 46-49.

14. Степанов Д.В Залежності для теплових розрахунків жаротрубних пучків котлів малої потужності / Д.В. Степанов, С.Й. Ткаченко, Л.А. Боднар, Т.Ю. Загаєцька // Вісник Вінницького політехнічного інституту. - 2006. - № 2. - С. 25-36. 